\section{Defective Glucose Counterregulation After Subcutaneous Insulin in Noninsulin-dependent Diabetes Mellitus \\ Paradoxical Suppression of Glucose Utilization \\ and Lack of Compensatory Increase in Glucose Production, Roles of Insulin Resistance, Abnormal Neuroendocrine Responses, and Islet Paracrine Interactions}

Geremia B. Bolli, Eva Tsalikian, Morey W. Haymond, Philip E. Cryer, and John E. Gerich

Endocrine Research Unit, Departments of Medicine and Physiology, Mayo Medical School and Mayo Clinic, Rochester, Minnesota 55901; Metabolism Division. Department of Medicine, Washington University School of Medicine, St. Louis, Missouri 63110 bstract. To characterize glucose counterregulatory mechanisms in patients with noninsulin-dependent diabetes mellitus (NIDDM) and to test the hypothesis that the increase in glucagon secretion during hypoglycemia occurs primarily via a paracrine islet A-B cell interaction, we examined the effects of a subcutaneously injected therapeutic dose of insulin $(0.15 \mathrm{U} / \mathrm{kg})$ on plasma glucose kinetics, rates of glucose production and utilization, and their relationships to changes in the circulating concentrations of neuroendocrine glucoregulatory factors (glucagon, epinephrine, norepinephrine, growth hormone, and cortisol), as well as to changes in endogenous insulin secretion in 13 nonobese NIDDM patients with no clinical evidence of autonomic neuropathy. Compared with 11 age-weight matched nondiabetic volunteers in whom euglycemia was restored primarily by a compensatory increase in glucose production, in the diabetics there was no compensatory increase in glucose production (basal $2.08 \pm 0.04 \rightarrow 1.79 \pm 0.07 \mathrm{mg} / \mathrm{kg}$ per min at $2 \frac{1}{2} \mathrm{~h}$ in diabetics vs. basal $2.06 \pm 0.04 \rightarrow 2.32 \pm 0.11 \mathrm{mg} / \mathrm{kg}$ per min at $2 \frac{1}{2} \mathrm{~h}$ in nondiabetics, $P<0.01$ ) despite the fact that

Dr. Bolli is the recipient of an International Research Fellowship from the Fogarty International Center (TW0-3229). Address correspondence and reprint requests to Dr. Gerich.

Received for publication 21 September 1983 and in revised form 27 February 1984.

J. Clin Invest.

(c) The American Society for Clinical Investigation, Inc.

$0021-9738 / 84 / 06 / 1532 / 10 \quad \$ 1.00$

Volume 73, June 1984, 1532-1541 plasma insulin concentrations were similar in both groups (peak values $22 \pm 2$ vs. $23 \pm 2 \mu \mathrm{U} / \mathrm{ml}$ in diabetics and nondiabetics, respectively). This abnormality in glucose production was nearly completely compensated for by a paradoxical decrease in glucose utilization after injection of insulin (basal $2.11 \pm 0.03 \rightarrow 1.86 \pm 0.06 \mathrm{mg} / \mathrm{kg}$ per min at $2^{1 / 2} \mathrm{~h}$ in diabetics vs. basal $2.08 \pm 0.04 \rightarrow 2.39 \pm 0.11 \mathrm{mg} /$ $\mathrm{kg}$ per min at $2 \frac{1}{2} \mathrm{~h}$ nondiabetics, $P<0.01$ ), which could not be accounted for by differences in plasma glucose concentrations; the net result was a modest prolongation of hypoglycemia. Plasma glucagon (area under the curve [AUC] above base line, $12 \pm 3$ vs. $23 \pm 3 \mathrm{mg} / \mathrm{ml} \cdot 12 \mathrm{~h}$ in nondiabetics, $P<0.05$ ), cortisol (AUC $2.2 \pm 0.5$ vs. $4.0 \pm 0.7 \mathrm{mg} / \mathrm{dl} \cdot 12 \mathrm{~h}$ in nondiabetics, $P<0.05$ ), and growth hormone (AUC $1.6 \pm 0.4$ vs. $2.9 \pm 0.4 \mu \mathrm{g} / \mathrm{ml} \cdot 12 \mathrm{~h}$ in nondiabetics, $P<0.05$ ) responses in the diabetics were decreased $50 \%$ while their plasma norepinephrine responses (AUC $49 \pm 12$ vs. $21 \pm 5 \mathrm{ng} / \mathrm{ml} \cdot 12 \mathrm{~h}$ in nondiabetics, $P<0.05)$ were increased twofold $(P<0.05)$ and their plasma epinephrine responses were similar to those of the nondiabetics (AUC $106 \pm 17$ vs. $112 \pm 10 \mathrm{ng} / \mathrm{ml} \cdot 12$ $h$ in nondiabetics). In both groups of subjects, increases in plasma glucagon were inversely correlated with plasma glucose concentrations $(r=-0.80$ in both groups, $P$ $<0.01)$ and suppression of endogenous insulin secretion ( $r=-0.57$ in nondiabetics and -0.64 in diabetics, both $P<0.05)$. The slope for the relationship between plasma glucagon responses and plasma glucose concentrations was reduced in the diabetics (1.2 vs. 2.3 in nondiabetics), suggesting decreased pancreatic A cell sensitivity to glucose. 
Our results thus indicate that glucose counterregulatory mechanisms are abnormal in patients with NIDDM: impaired glucagon, growth hormone, cortisol, and perhaps epinephrine responses during hypoglycemia could all contribute to a lack of compensatory increase in glucose production while near normal (epinephrine) and increased (norepinephrine) release of catecholamines in the presence of resistance to insulin in peripheral tissues may explain the accompanying suppression of glucose utilization. The inverse relationship between increases in plasma glucagon and suppression of insulin secretion observed during hypoglycemia in both nondiabetic and diabetic subjects is incompatible with the concept that deinhibition of glucagon secretion via a paracrine islet A-B cell interaction is a major factor responsible for the increase in glucagon secretion during hypoglycemia. Our results suggest that the plasma glucagon response to hypoglycemia is predominantly the result of a stimulatory effect of decreased extracellular glucose concentrations on the A cell.

\section{Introduction}

It is well established that glucose counterregulatory mechanisms are abnormal in insulin-dependent diabetes mellitus (IDDM) ${ }^{1}$ $(1-12)$. During insulin-induced hypoglycemia in patients with this disorder, plasma glucagon generally does not increase (212); plasma epinephrine responses are frequently blunted (5$12)$, even in the absence of clinically detectable autonomic neuropathy (6, 7-12); and sometimes plasma growth hormone and cortisol responses are impaired $(3,8,11,12)$. As a result of these abnormalities there is an exaggerated suppression of hepatic glucose production $(4,8,9,12)$, which may lead to severe and prolonged hypoglycemia $(8,9,12)$.

In contrast, relatively little is known concerning glucose counterregulation in patients with noninsulin-dependent diabetes mellitus (NIDDM). In the four previous studies that we are aware of that dealt with this issue, $(3,13-15)$, no consensus was reached concerning the appropriateness of counterregulatory hormone responses $(3,13-15)$. Furthermore, no data are presently available concerning changes in glucose production and glucose utilization or the ability to restore euglycemia. The occurrence of prolonged hypoglycemia unassociated with hyperinsulinemia during sulfonylurea treatment suggests that glucose counterregulation may be impaired in some patients with $\operatorname{NIDDM}(16,17)$.

The pancreatic A cell response to hypoglycemia in patients with NIDDM is of particular interest, not only because of its important role in glucose counterregulation (1) but also because

1. Abbreviations used in this paper: AUC, area under the curve; IDDM, insulin-dependent diabetes mellitus; NIDDM, noninsulin-dependent diabetes mellitus. of the recently proposed hypothesis $(18,19)$ that the A cell response to hypoglycemia is primarily due to a paracrine islet A-B cell interaction. According to this hypothesis, the decrease in insulin secretion that occurs during hypoglycemia (20) lowers intraislet insulin concentrations and causes deinhibition of glucagon secretion due to locally released insulin. It has been suggested that the lack of this decrease in intraislet insulin concentrations may explain the absence of a plasma glucagon response during hypoglycemia in IDDM $(18,19)$. Since patients with NIDDM still maintain some $B$ cell function, albeit decreased (21), examination of the relationship between changes in insulin secretion and plasma glucagon responses during hypoglycemia affords the opportunity to test this hypothesis.

The present studies were therefore undertaken to characterize glucose counterregulatory mechanisms in NIDDM and to test the hypothesis that the increase in glucagon secretion during hypoglycemia occurs primarily via a paracrine islet A-B cell interaction. For these purposes we examined the effects of a subcutaneously injected therapeutic dose of insulin on plasma glucose kinetics, and on rates of glucose production and glucose utilization and their relationships to changes in the circulating concentrations of neuroendocrine glucoregulatory factors (glucagon, epinephrine, norepinephrine, growth hormone and cortisol), as well as changes in endogenous insulin secretion in 13 nonobese NIDDM patients without clinical evidence of autonomic neuropathy and in 11 age-weight-matched nondiabetic volunteers. Our results indicate that in NIDDM there are multiple defects in glucose counterregulatory mechanisms, and provide evidence against the hypothesis that increases in glucagon secretion during hypoglycemia result from a paracrine islet AB cell interaction.

\section{Methods}

Subjects. Informed written consent was obtained from 13 nonobese patients with NIDDM and from 11 normal volunteers matched for mean age and weight who had no family history of diabetes. The clinical features of the subjects are detailed in Table I. Relatively more women were present in the control group. The diabetic subjects were otherwise healthy and had no symptoms or clinical evidence of autonomic neuropathy, as assessed by the methods of Hilsted et al. (22) and Ewing et al. (23).

Protocol. All subjects were studied in the postabsorptive state after an overnight fast. The diabetic subjects being treated with insulin were withdrawn from their intermediate-acting insulin (NPH or lente) for 48 $\mathrm{h}$ before the study and were managed by 3-4 daily preprandial subcutaneous injections of regular insulin, the last of which was given at least $16 \mathrm{~h}$ before the study. The one diabetic being treated with a sulfonylurea agent had this medication stopped $1 \mathrm{wk}$ before the study. On the evening before the study, the diabetic subjects were admitted to the Mayo Clinic Clinical Study Unit, connected to a closed-loop insulin infusion device (biostator; Life Science Instruments Div., Miles Laboratories Inc., Elkhart, IN), and were maintained euglycemic (84-99 mg/ $\mathrm{dl}$, venous blood) overnight (at least $10 \mathrm{~h}$ ) by intravenous infusions of insulin $(0.18 \pm 0.02 \mathrm{mU} / \mathrm{kg}$ per $\mathrm{min})$. Nondiabetic subjects were admitted to the Clinical Study Unit between 6 and 7 a.m. of the study day and placed at bedrest. 
Table I. Clinical Characteristics of Subjects Studied

\begin{tabular}{|c|c|c|c|c|}
\hline & \multirow{2}{*}{$\begin{array}{l}\text { Nondiabetic } \\
\text { volunteers }(n=11)\end{array}$} & \multicolumn{3}{|l|}{ Patients with NIDDM } \\
\hline & & All $(n=13)$ & Insulin treated $(n=8)$ & Noninsulin treated $(n=5)$ \\
\hline Age $(y r)$ & $42 \pm 3$ & $46 \pm 3$ & $40 \pm 3$ & $56 \pm 2^{*}$ \\
\hline Ideal body weight (\%) & $101 \pm 2$ & $103 \pm 1$ & $103 \pm 1$ & $102 \pm 1$ \\
\hline Sex & $5 \mathrm{M}, 6 \mathrm{~F}$ & $10 \mathrm{M}, 3 \mathrm{~F}$ & $5 \mathrm{M}, 3 \mathrm{~F}$ & $5 \mathrm{M}$ \\
\hline Fasting plasma glucose $(\mathrm{mg} / \mathrm{dl})$ & $95 \pm 2$ & $136 \pm 6 \ddagger$ & $141 \pm 10$ & $127 \pm 4$ \\
\hline Duration of diabetes & - & $4.5 \pm 1.0$ & $4.1 \pm 1.5$ & $5.0 \pm 1.7$ \\
\hline Treatment & - & $\begin{array}{l}\text { Insulin } 8 \\
\text { Diet alone } 4 \\
\text { Diet + sulfonylurea 1 }\end{array}$ & $\begin{array}{l}27 \pm 9 \\
\mathrm{U} / \mathrm{d}\end{array}$ & $\begin{array}{l}\text { Diet alone } 4 \\
\text { Tolazamide } 1 \\
\text { ( } 250 \mathrm{mg} \text { twice daily) }\end{array}$ \\
\hline Glycosylated hemoglobin (\%) & $7.5 \pm 0.3$ & $9.0 \pm 0.2 \ddagger$ & $8.9 \pm 0.3$ & $9.2 \pm 0.2$ \\
\hline Insulin antibody binding (\%) & $1.1 \pm 0.1$ & $1.9 \pm 0.4$ & $2.5 \pm 0.5$ & $1.1 \pm 0.1^{*}$ \\
\hline $\begin{array}{l}\text { Beat-to-beat variation } \\
\text { (beats } / \mathrm{min})\end{array}$ & $>20$ & $29 \pm 1$ & $30 \pm 1$ & $27 \pm 3$ \\
\hline $\begin{array}{l}\text { Change in systolic pressure after } \\
\text { standing } 1 \mathrm{~min}(\mathrm{mmHg})\end{array}$ & $<15$ & $5 \pm 1$ & $6 \pm 1$ & $4 \pm 1$ \\
\hline $\begin{array}{l}\text { C-Peptide response to } \\
\text { intravenous glucagon }(\mathrm{ng} / \mathrm{ml}) \text {, } \\
0 \mathrm{~min}, 6 \mathrm{~min}\end{array}$ & $\begin{array}{l}1.38 \pm 0.11 \\
4.00 \pm 0.47\end{array}$ & $\begin{array}{l}0.67 \ddagger \pm 0.10 \\
1.29 \ddagger \mp 0.24\end{array}$ & $\begin{array}{l}0.48 \pm 0.07 \\
0.76 \pm 0.16\end{array}$ & $\begin{array}{l}0.98^{*} \pm 0.18 \\
2.14^{*} \pm 0.33\end{array}$ \\
\hline
\end{tabular}

* $P<0.05$, insulin treated vs. noninsulin-treated diabetics. $¥ P<0.05$, nondiabetics vs. diabetics.

In both groups of subjects a hand vein was cannulated retrogradely with a 19-gauge butterfly needle and the hand was maintained in a thermoregulated box $\left(55^{\circ} \mathrm{C}\right)$ for intermittent sampling of arterializedvenous blood (24). A primed (18 $\mu \mathrm{Ci})$ continuous $(0.18 \mu \mathrm{Ci} / \mathrm{min})$ infusion of $\left[{ }^{3}-3 \mathrm{H}\right]$ glucose (New England Nuclear, Boston, MA) was begun in a contralateral forearm vein for determination of rates of glucose production and utilization; at least $2 \mathrm{~h}$ were allowed for isotopic equilibration. After obtaining base-line blood samples, regular pork insulin $(0.15 \mathrm{U} / \mathrm{kg}$, U100, Iletin II; Eli Lilly \& Co., Indianapolis, IN) was injected in the abdomen $2 \mathrm{~cm}$ to the right or left of the umbilicus.

Analytical techniques. Blood samples were collected at 30-min intervals over $12 \mathrm{~h}$ for determination of plasma glucose (YSI glucose analyzer; Yellow Springs Instrument Co., Yellow Springs, $\mathrm{OH}$ ), glucose radioactivity (25), free insulin (both in controls and diabetic subjects) (26), glucagon (27), C-peptide (28), epinephrine (29), norepinephrine (29), cortisol (30), growth hormone (31), free fatty acids (32), and $\beta$-hydroxybutyrate (33) by previously described methods. Rates of glucose production and utilization were calculated using the nonsteadystate equations of DeBodo et al. (34) and were "smoothed" according to the method of Miles et al. (35). Insulin secretion rates were calculated based on changes in plasma $C$-peptide concentrations using equations derived from a two compartmental model (36); a distribution space for C-peptide of $80 \mathrm{ml} / \mathrm{kg}$ was used instead of the $41-\mathrm{ml} / \mathrm{kg}$ distribution space of albumin originally proposed, since analysis of the C-peptide data (37) from which the fractional disappearance rates for C-peptide were obtained for the model yielded a distribution space of $80 \mathrm{ml} / \mathrm{kg}$. Insulin antibody binding was determined by a modification of the method of Goldman et al. (38). Glycosylated hemoglobin was determined by a microcolumn ion exchange method (39) after a 6-h incubation of erythrocytes in $0.9 \%$ saline.

Statistical analyses. Unless stated otherwise, data in text and figures are given as mean $\pm \mathrm{SE}$ of the mean; paired data were analyzed using one-way analysis of variance corrected for repeated measurements, and unpaired data were analyzed using the Rank Sum Test (40). A $P$ value $<0.05$ was considered significant. The correlation between plasma glucagon responses and plasma glucose concentration, suppression of endogenous insulin secretion, C-peptide responses to glucagon, and basal insulin, insulin secretion rates were first examined using multivariate analysis and, after it was determined that plasma glucagon responses were correlated with one of these parameters independent of the plasma glucose concentration, these relationships were examined using least squares linear regression (40).

\section{Results}

Plasma insulin, C-peptide, and insulin secretion rate (Fig. 1). Before injection of insulin, plasma insulin concentrations in the diabetics, who were being infused with insulin, were greater than those of the nondiabetics $(11 \pm 2$ vs. $7 \pm 1 \mu \mathrm{U} / \mathrm{ml}$, respectively, $P<0.01)$. After injection of insulin, plasma insulin concentrations increased to similar peak levels in diabetics $(22 \pm 2 \mu \mathrm{U} /$ $\mathrm{ml})$ and nondiabetics $(23 \pm 2 \mu \mathrm{U} / \mathrm{ml})$ between 1 and $3 \mathrm{~h}$, and 

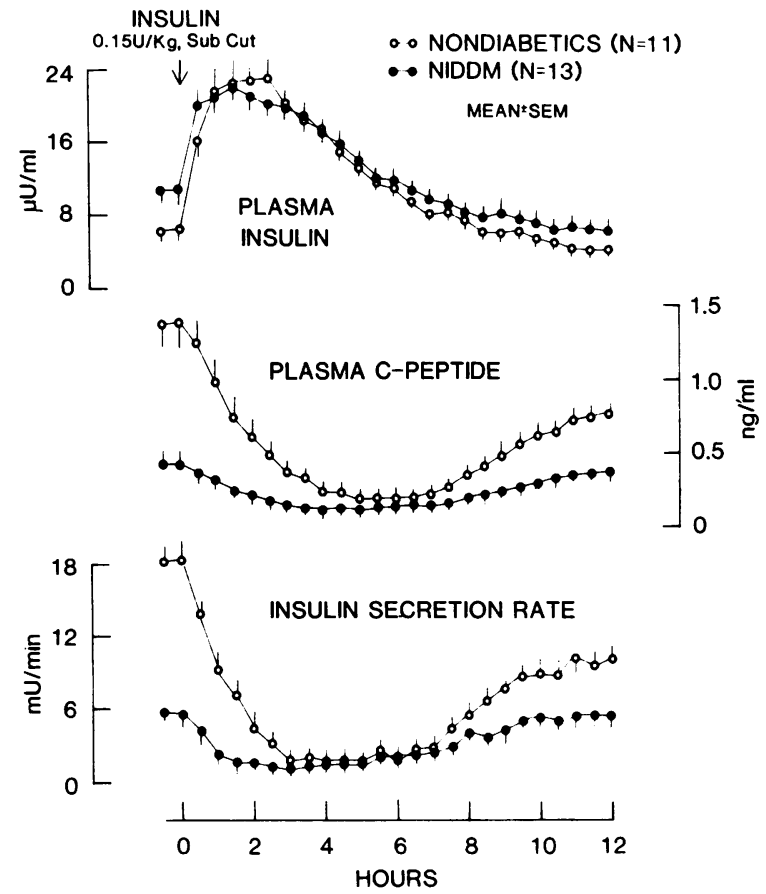

Figure 1. Plasma insulin and C-peptide concentrations and insulin secretion rates after subcutaneous injection (Sub Cut) of insulin in nondiabetic volunteers and patients with NIDDM.

subsequently returned to basal values between 6 and $8 \mathrm{~h}$. After injection of insulin, plasma insulin concentrations in the diabetics and nondiabetics were not significantly different at any time during the study.

Before injection of insulin, plasma C-peptide concentrations in diabetics were significantly less than those of nondiabetics $(0.43 \pm 0.08$ vs. $1.40 \pm 0.14 \mathrm{ng} / \mathrm{ml}, P<0.01)$. After injection of insulin, plasma C-peptide concentrations decreased in both diabetics and nondiabetics to similar nadirs $(0.13 \pm 0.02$ vs. $0.18 \pm 0.02 \mathrm{ng} / \mathrm{ml}$, respectively) between 4 and $6 \mathrm{~h}$, and subsequently increased progressively to $0.38 \pm 0.06$ and $0.77 \pm 0.07 \mathrm{ng} /$ $\mathrm{ml}$, respectively, at $12 \mathrm{~h}(P<0.01$, diabetics vs. nondiabetics).

Before injection of insulin, calculated rates of insulin secretion in the diabetics were only one-third the rates in the nondiabetics $(5.6 \pm 1.0$ vs. $18.6 \pm 1.9 \mathrm{mU} / \mathrm{min}$, respectively, $P$ $<0.01)$. After injection of insulin, insulin secretion rates decreased $>85 \%$ in diabetics and nondiabetics (to $0.9 \pm 0.1$ vs. $0.6 \pm 0.2 \mathrm{mU} / \mathrm{min}$, respectively) between 4 and $6 \mathrm{~h}$, and subsequently increased progressively to $5.4 \pm 1.4$ and $10.1 \pm 1.0 \mathrm{mU} /$ min, respectively, after $12 \mathrm{~h}(P<0.01$, diabetics vs. nondiabetics).

Plasma glucose concentrations and rates of glucose production and utilization (Fig. 2, Table II). Before injection of insulin, plasma glucose concentrations were not significantly different in diabetics $(97 \pm 2 \mathrm{mg} / \mathrm{dl})$ and nondiabetics $(94 \pm 1 \mathrm{mg} / \mathrm{dl})$. After injection of insulin, plasma glucose decreased in both groups to similar nadirs between 3 and $5 \mathrm{~h}(61 \pm 4$ vs. $62 \pm 2 \mathrm{mg} / \mathrm{dl}$ in diabetics and nondiabetics, respectively). The subsequent rate of increase in plasma glucose was significantly less in the diabetics than in the nondiabetics $(2.4 \pm 0.4$ vs. $3.6 \pm 0.4 \mathrm{mg} / \mathrm{dl}$ per $\mathrm{min}$, respectively, $P<0.05$ ), so that during the last $8 \mathrm{~h}$ of the study the mean plasma glucose concentration in the diabetics was significantly lower than that of the nondiabetics ( $68 \pm 2$ vs. $76 \pm 1$ $\mathrm{mg} / \mathrm{dl}, P<0.05)$. Responses in insulin-treated diabetics did not differ significantly from responses in the noninsulin-treated diabetics (Table II). Postnadir rates of increase in plasma glucose concentration were negatively correlated with insulin secretion rates during this period in both diabetics $(r=-0.63, P<0.05)$ and nondiabetics $(r=-0.64, P<0.05)$.

Before injection of insulin, rates of glucose production $(2.08 \pm 0.04$ vs. $2.06 \pm 0.04 \mathrm{mg} / \mathrm{kg}$ per $\mathrm{min})$ and utilization $(2.11 \pm 0.03$ vs. $2.08 \pm 0.04 \mathrm{mg} / \mathrm{kg}$ per $\mathrm{min})$ were comparable in the diabetics and nondiabetics. Following injection of insulin, glucose production decreased in both groups. In the nondiabetics, glucose production reached a nadir at $1 \mathrm{~h}(1.73 \pm 0.05 \mathrm{mg} / \mathrm{kg}$ per $\min$ ) and then increased above base-line values to a peak of $2.36 \pm 0.10 \mathrm{mg} / \mathrm{kg}$ per min at $4 \mathrm{~h}$. In contrast, glucose production remained suppressed throughout in the diabetics. Glucose utilization did not change for $1 \frac{1}{2} \mathrm{~h}$ after injection of insulin in both groups. In the nondiabetics, glucose utilization increased above base line to a peak value of $2.39 \pm 0.11 \mathrm{mg} / \mathrm{kg}$ per min at $2 \frac{1}{2} \mathrm{~h}$; in contrast, in the diabetics, glucose utilization decreased progressively. Similar responses were observed in insulin-treated and noninsulin-treated diabetics (data not shown).

Plasma free fatty acids and $\beta$-hydroxybutyrate concentrations

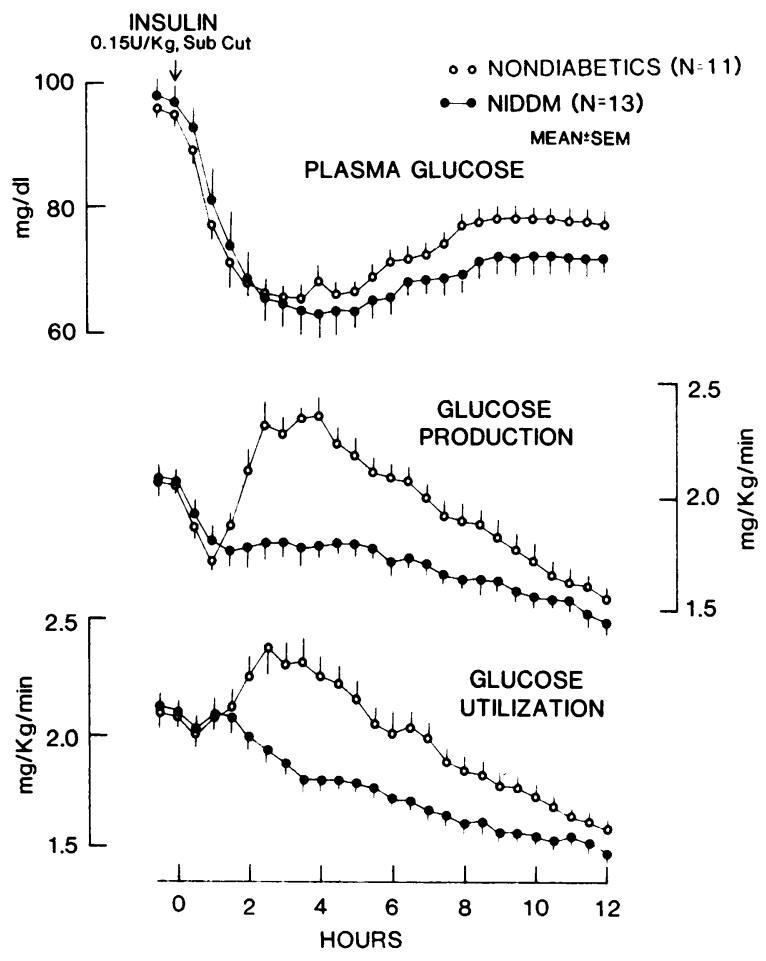

Figure 2. Plasma glucose concentrations and rates of glucose production and utilization after subcutaneous injection (Sub Cut) of insulin in nondiabetic volunteers and patients with NIDDM. 
Table II. Plasma Glucose, Glucagon, Epinephrine,

Norepinephrine, Growth Hormone, and Cortisol Responses to Insulin-induced Hypoglycemia in Nondiabetic Volunteers and Patients with NIDDM

\begin{tabular}{|c|c|c|c|c|}
\hline & \multirow[b]{2}{*}{$\begin{array}{l}\text { Nondiabetic } \\
\text { volunteers } \\
(n=11)\end{array}$} & \multicolumn{3}{|c|}{ Patients with NIDDM } \\
\hline & & $\begin{array}{l}\text { All } \\
(n=13)\end{array}$ & $\begin{array}{l}\text { Insulin } \\
\text { treated } \\
(n=8)\end{array}$ & $\begin{array}{l}\text { Noninsulin } \\
\text { treated } \\
(n=5)\end{array}$ \\
\hline $\begin{array}{l}\text { Plasma glucose nadir } \\
(m g / d l)\end{array}$ & $62 \pm 2$ & $61 \pm 4$ & $57 \pm 5$ & $67 \pm 5$ \\
\hline Rate of post nadir & & & & \\
\hline $\begin{array}{l}\text { Plasma glucose increase } \\
(m g / d l \cdot h)\end{array}$ & $3.6 \pm 0.4$ & $2.4 \pm 0.4^{*}$ & $2.7 \pm 0.6$ & $2.2 \pm 0.3$ \\
\hline $\begin{array}{l}\text { Plasma glucagon } \\
\text { response }(\mathrm{mg} / \mathrm{ml} \cdot 12 \mathrm{~h})\end{array}$ & $23 \pm 3$ & $12 \pm 3^{*}$ & $15 \pm 5$ & $8 \pm 2$ \\
\hline $\begin{array}{l}\text { Plasma epinephrine } \\
\text { response }(\mathrm{ng} / \mathrm{ml} \cdot 12 \mathrm{~h})\end{array}$ & $112 \pm 10$ & $106 \pm 17$ & $105 \pm 20$ & $107 \pm 47$ \\
\hline $\begin{array}{l}\text { Plasma norepinephrine } \\
\text { response }(\mathrm{ng} / \mathrm{ml} \cdot 12 \mathrm{~h})\end{array}$ & $21 \pm 5$ & $49 \pm 12^{*}$ & $62 \pm 18$ & $27 \pm 7$ \\
\hline $\begin{array}{l}\text { Plasma cortisol } \\
\text { response }(\mathrm{mg} / \mathrm{dl} \cdot 12 \mathrm{~h})\end{array}$ & $4.0 \pm 0.7$ & $2.2 \pm 0.5^{*}$ & $2.6 \pm 0.7$ & $1.5 \pm 0.2$ \\
\hline $\begin{array}{l}\text { Plasma growth hormone } \\
\text { response }(\mu \mathrm{g} / \mathrm{ml} \cdot 12 \mathrm{~h})\end{array}$ & $2.9 \pm 0.4$ & $1.6 \pm 0.4^{*}$ & $1.8 \pm 0.6$ & $1.2 \pm 0.5$ \\
\hline
\end{tabular}

* $P<0.05$, nondiabetics vs. diabetics.

(Fig. 3). Before injection of insulin, plasma free fatty acid and $\beta$-hydroxybutyrate concentrations were similar in diabetics $(0.40 \pm 0.06$ and $0.20 \pm 0.05 \mathrm{mM}$, respectively) and nondiabetics $(0.36 \pm 0.04$ and $0.23 \pm 0.05 \mathrm{mM}$, respectively). After injection of insulin in the nondiabetics, both plasma free fatty acid and $\beta$-hydroxybutyrate levels decreased initially (to $0.12 \pm 0.02$ and $0.02 \pm 0.01 \mathrm{mM}$, respectively, at $2 \mathrm{~h}, P<0.01$ ), and then increased progressively to $0.86 \pm 0.06$ and $0.90 \pm 0.16 \mathrm{mM}$, respectively, at $12 \mathrm{~h}, P<0.01$. In contrast, in the diabetics, neither plasma free fatty acid nor $\beta$-hydroxybutyrate levels decreased after injection of insulin. Plasma free fatty acids were similar in diabetics $(0.98 \pm 0.09 \mathrm{mM})$ and nondiabetics at $12 \mathrm{~h}$ but plasma $\beta$-hydroxybutyrate concentrations were nearly twofold greater in the diabetics $(1.72 \pm 0.38 \mathrm{mM}, P<0.01)$. Responses in insulin-treated and noninsulin-treated diabetics were similar (data not shown).

Plasma glucagon, epinephrine, norepinephrine, growth hormone, and cortisol responses (Fig. 4, Table II). Before injection of insulin, plasma glucagon ( $95 \pm 9$ vs. $103 \pm 13 \mathrm{pg} / \mathrm{ml})$, epinephrine $(43 \pm 5$ vs. $41 \pm 5 \mathrm{pg} / \mathrm{ml})$, norepinephrine $(214 \pm 14$ vs. $251 \pm 15 \mathrm{pg} / \mathrm{ml})$, growth hormone $(1.9 \pm 0.5$ vs. $1.2 \pm 0.3 \mathrm{pg} / \mathrm{ml})$, and cortisol $(8.7 \pm 0.7$ vs. $9.7 \pm 1.2 \mu \mathrm{g} / \mathrm{dl})$ were comparable in diabetics and nondiabetics, and each increased to peak values between 3 and $5 \mathrm{~h}$ in both groups (Fig. 4). Despite the fact that the diabetics had significantly lower plasma glucose concentrations during the last $8 \mathrm{~h}$ of the study, their overall plasma glucagon, growth hormone, and cortisol responses were all decreased nearly $50 \%$ compared with responses in the nondiabetics $(P$ $<0.05$ ), whereas their plasma norepinephrine responses were increased more than twofold $(P<0.05)$ and their plasma epinephrine responses were similar to those of the nondiabetics; responses in insulin-treated diabetics were not significantly different from those of noninsulin-treated diabetics (Table II).

Relationship between plasma glucagon responses, plasma glucose concentrations, and changes in insulin secretion (Fig. 5). To examine pancreatic A cell responses in further detail, the relationships between increments in plasma glucagon, plasma glucose concentration, and percentage of suppression of endogenous insulin secretion at $3 \mathrm{~h}$ after injection of insulinthe time at which plasma glucagon responses were maximal and both plasma glucose and insulin secretion were at their nadirs-were assessed using multivariate analysis.

There was a significant correlation between the increment in plasma glucagon and the level to which the plasma glucose concentration had decreased in both nondiabetics (partial correlation coefficient $-0.80, P<0.006$ ) and diabetics (partial correlation coefficient $-0.80, P<0.002$ ). Linear regression analysis of the increment in plasma glucagon vs. the plasma glucose concentration (Fig. 5, left) yielded intercepts that were similar in both groups ( $94 \mathrm{vs} .93 \mathrm{mg} / \mathrm{dl}$ in diabetics and nondiabetics, respectively), but the slope was nearly twice as great in the nondiabetics as in the diabetics ( 2.3 vs. 1.2$)$. There was also a significant inverse relationship between plasma glucagon responses and suppression of insulin secretion (Fig. 5, right) in both the diabetics (partial correlation coefficient $-0.78, P$ $<0.003$ ) and in the nondiabetics (partial correlation coefficient $-0.70, P<0.02$ ), indicating that, independent of changes in plasma glucose concentration, the less the suppression of endogenous insulin secretion the greater the plasma glucagon response. There was no significant correlation between plasma glucagon responses to hypoglycemia and either base-line insulin secretion rate or plasma $C$-peptide responses to intravenous glucagon, an index of B cell reserve (41), in either nondiabetics or diabetics. Furthermore, no correlation was found between plasma glucagon responses and either fasting plasma glucose concentration, $\mathrm{HA}_{1} \mathrm{C}$, or duration of diabetes in the diabetics.

\section{Discussion}

The present studies demonstrate that glucose counterregulatory mechanisms are abnormal in insulin-treated and noninsulintreated patients with NIDDM. The most striking abnormalities

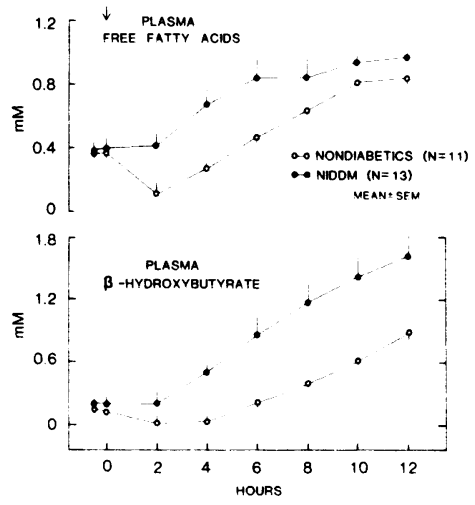

Figure 3. Plasma free fatty acid and $\beta$-hydroxybutyrate concentrations after subcutaneous injection of insulin in nondiabetic volunteers and patients with NIDDM. 

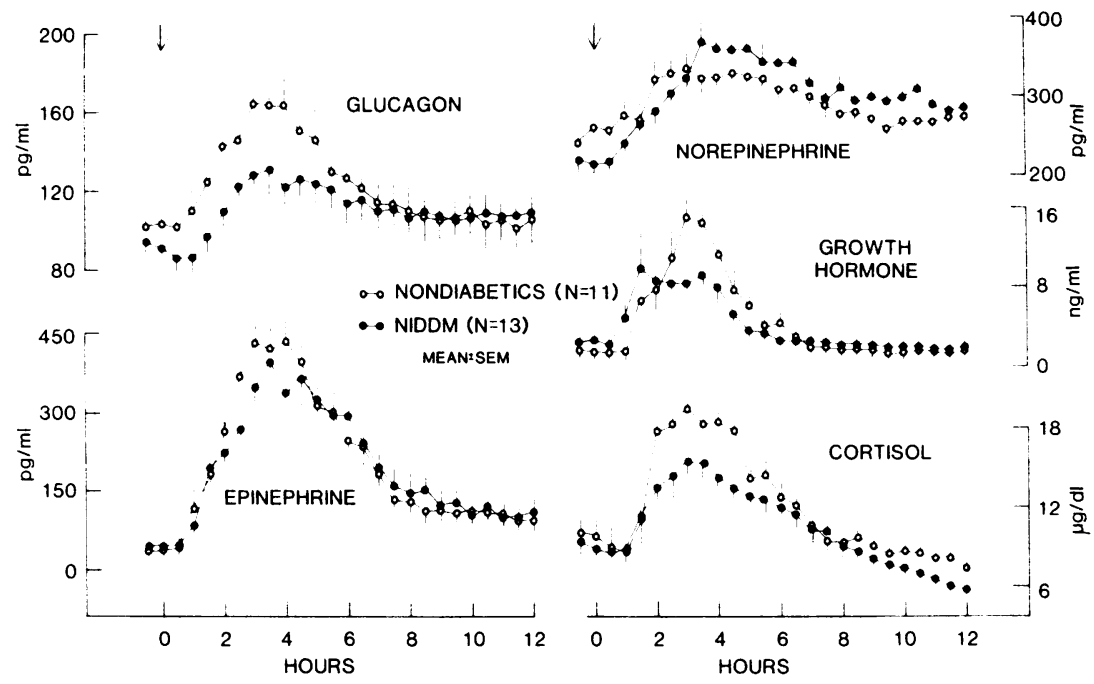

Figure 4. Plasma glucagon, epinephrine, norepinephrine, growth hormone, and cortisol concentrations after subcutaneous injection of insulin in nondiabetic volunteers and patients with NIDDM.

were an absence of a compensatory increase in glucose production and a paradoxical decrease in glucose utilization after administration of insulin. The net result of these alterations, however, was only a modest prolongation of hypoglycemia. Accompanying these abnormalities were deficiencies in the responses of several counterregulatory hormones (glucagon, growth hormone, and cortisol); an excessive increase in the plasma norepinephrine response was also observed, but this may have been appropriate for the prolonged hypoglycemia. Indeed, plasma epinephrine responses may also have been impaired, since the more prolonged hypoglycemia in the diabetics should have evoked a greater than normal epinephrine response.

The abnormality in glucose production in the diabetics occurred during a period in which systemic plasma insulin and C-peptide concentrations as well as calculated rates of insulin secretion were either similar to or lower than corresponding values in the nondiabetics. This observation and the fact that

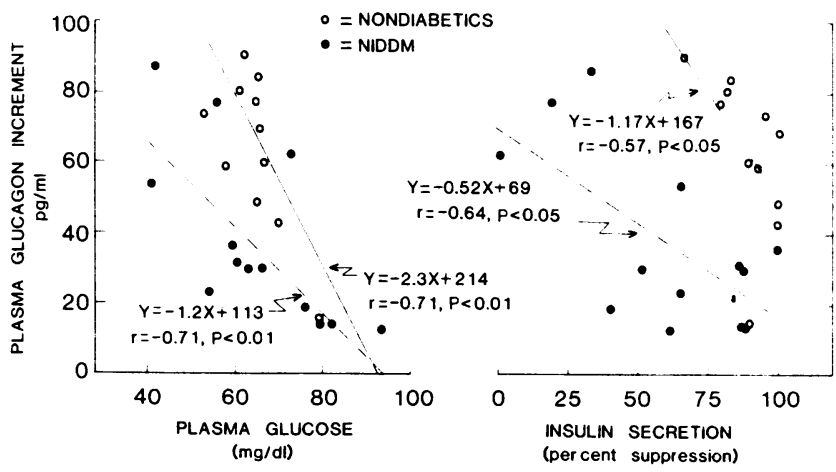

Figure 5. Relationship between increases in plasma glucagon and plasma glucose concentrations (left) and suppression of insulin secretion (right) during hypoglycemia induced by subcutaneous injection of insulin in nondiabetic volunteers and patients with NIDDM (values at $3 \mathrm{~h}$ were used). resistance to the suppressive effect of insulin on hepatic glucose production has been recently demonstrated in NIDDM patients in dose-response experiments using the euglycemic clamp technique $(42,43)$, strongly suggest that the exaggerated suppression of glucose production was the result of impaired counterregulatory mechanisms rather than of increased intrinsic sensitivity to insulin or exposure of the liver to increased insulin concentrations.

The only neuroendocrine abnormality evident before or coincident with the appearance of the discrepant rates of glucose production in the diabetic and nondiabetic subjects was that of plasma glucagon, which had increased only $25 \%$ as much in the diabetics as in the nondiabetics $(7 \pm 5$ vs. $27 \pm 8 \mathrm{pg} / \mathrm{ml}$, respectively, at $90 \mathrm{~min}, P<0.01$ ). Given the importance of changes in glucagon availability of this magnitude on hepatic glucose production $(44,45)$, it thus seems quite likely that the impaired plasma glucagon response of the diabetics contributed to their exaggerated suppression of glucose production after insulin administration. This conclusion is supported by the observation that prevention of the plasma glucagon response during hypoglycemia induced by intravenous insulin enhances suppression of glucose production and markedly attenuates the subsequent compensatory increase (46).

However, the impaired plasma glucagon response may not wholly account for the lack of compensatory increase in glucose production in the diabetics. Prevention of increases in plasma glucagon during insulin-induced hypoglycemia using somatostatin usually does not produce total lack of a compensatory increase in glucose production (46), as was observed in the present study in diabetics who had only a $50 \%$ decreased plasma glucagon response. After $3 \mathrm{~h}$, plasma growth hormone and cortisol responses were also decreased in the diabetics. Since these hormones can antagonize the suppressive effect of insulin on glucose production (47-49) and have synergistic interactions with other counterregulatory hormones $(50)$, it is possible that the decreased plasma growth hormone and cortisol responses 
may also have contributed to the lack of compensatory increase in glucose production in the diabetics.

Although catecholamines are thought to play an important role during glucose counterregulation in normal man $(51,52)$, and especially in patients with $\operatorname{IDDM}(1,6,7,53)$, it is clear that the augmented norepinephrine and apparently normal epinephrine responses were not able to compensate completely for the effects on glucose production of impaired response of the other counterregulatory factors. Theoretically, abnormal hepatic autoregulation (54) might have been an additional factor, but current evidence suggests that this process does not play a major role in glucose counterregulation $(1,51)$.

Another prominent abnormality accompanying the exaggerated suppression of glucose production in the diabetics was a sustained paradoxical decrease in glucose utilization after administration of insulin. This decreased rate of glucose utilization almost completely compensated for the exaggerated suppression of glucose production, so that there was only a modest prolongation of hypoglycemia. Thus, in contrast to the situation in nondiabetics, where a compensatory increase in glucose production is a major mechanism responsible for restoration of euglycemia after insulin-induced hypoglycemia $(46,52,55)$, in patients with NIDDM who lack such a compensatory increase, suppression of glucose utilization is the predominant mechanism responsible for restoration of euglycemia.

The cause for this paradoxical suppression of glucose utilization is unclear. This phenomenon was most apparent during the initial $3 \frac{1}{2} \mathrm{~h}$ after insulin administration, a period during which glucose utilization had increased in the nondiabetics. Plasma insulin and glucose concentrations were nearly identical in nondiabetics and diabetics during this period, thus excluding differences in insulin availability and in mass action effects of glucose as possible explanations. Since plasma growth hormone and cortisol concentrations were lower in the diabetics and their plasma epinephrine concentrations were similar to values in the nondiabetics, it is unlikely that differences in the secretion of these hormones were involved.

Although plasma norepinephrine increased to a greater extent in the diabetics, the concentrations achieved were below the threshold for norepinephrine to have exerted an effect as a hormone (56). However, it is conceivable that norepinephrine may have exerted an effect via its increased release from sympathetic neurons or that its increased circulating levels may have acted in concert with the apparently normal plasma epinephrine levels. The recent observations that beta adrenergic blockade augments glucose clearance in patients with IDDM during insulin-induced hypoglycemia (57) and reverses suppression of glucose clearance during infusion of epinephrine in normal man (58) suggest that catecholamines may have been involved.

Other factors that may have diminished the ability of insulin to increase glucose utilization in the diabetics include resistance to insulin and/or increased sensitivity to counterregulatory hormones in peripheral tissues. Insulin resistance and increased sensitivity of peripheral tissues to counterregulatory hormones have been demonstrated in patients with diabetes mellitus $(42$,
43, 59). Evidence for the presence of peripheral tissue resistance to insulin in the diabetics during the present study is the observation of impaired suppression of lipolysis in the diabetics after administration of insulin. Thus, peripheral tissues of the diabetics would be expected to be more sensitive to counterregulatory hormones. Since growth hormone and cortisol responses were decreased, our data are most consistent with an interaction between insulin resistance and the near normal epinephrine and increased norepinephrine responses as the most likely explanation for the paradoxical decrease in glucose utilization in the NIDDM patients.

Abnormalities in glucose counterregulation qualitatively similar to those found in the present study in patients with NIDDM are found in patients with IDDM (1-12). However, greater and more prolonged hypoglycemia generally occurs in patients with IDDM $(6-12)$ and is frequently followed by rebound hyperglycemia $(6,12)$. The greater hypoglycemia in IDDM appears to be largely explicable on the basis of a prolonged half-life of insulin, due to the presence of insulin antibodies (7, 12) along with more severe impairment in neuroendocrine counterregulatory responses, since, for example, plasma glucagon responses are generally absent and plasma epinephrine responses are frequently blunted in IDDM (1-12), whereas in patients with NIDDM in the present study plasma glucagon responses were merely blunted and plasma epinephrine responses were similar to those of the nondiabetic subjects. It should be pointed out, however, that the NIDDM patients examined in the present study had relatively mild diabetes of short duration, and in those treated with insulin, insulin antibody binding was quite low. It is thus possible that abnormalities as severe as those found in IDDM may occur in NIDDM patients with diabetes of greater severity and longer duration.

The lack of posthypoglycemic hyperglycemia in patients with NIDDM seems most likely to be related to their residual islet $B$ cell function. In the present study, insulin secretion increased in patients with NIDDM as plasma glucose concentrations increased toward normoglycemic values, so that by the end of the study insulin secretion rates in the diabetics were about one-half the rates seen in the nondiabetics. Furthermore, a significant negative correlation was observed between rates of increase in plasma glucose concentrations and insulin secretion rates during this period in the diabetics. In patients with IDDM who develop posthypoglycemic hyperglycemia when studied under conditions similar to those of the present study and who are more severely insulin deficient, rates of increase in plasma glucose concentrations after insulin-induced hypoglycemia are inversely correlated with residual circulating insulin concentrations (12).

The cause of the impaired pancreatic A cell response to hypoglycemia in patients with diabetes mellitus has been the subject of much speculation $(1,17,18,60-62)$. Most recently it has been proposed that a paracrine islet A-B cell interaction is normally the major determinant of the increase in glucagon secretion during hypoglycemia $(18,19)$. According to this hypothesis, the decrease in insulin secretion that occurs during 
hypoglycemia lowers intraislet insulin concentrations and causes deinhibition of glucagon secretion due to insulin. It has been further proposed $(18,19)$ that lack of this decrease in intraislet insulin concentrations may explain the absence of a plasma glucagon response during hypoglycemia in patients with IDDM. The finding in the present study of a reduced plasma glucagon response to insulin-induced hypoglycemia in NIDDM patients with a reduced B cell secretory capacity (assessed by the glucagonstimulation test) would seem to support this hypothesis.

However, if this hypothesis were correct, one would have anticipated finding a positive correlation between suppression of insulin secretion and plasma glucagon responses during hypoglycemia. In fact, the opposite was found; namely, in both nondiabetics and diabetics there was a negative correlation between suppression of insulin secretion and plasma glucagon responses during hypoglycemia. Furthermore, in both nondiabetics and diabetics, there was no correlation between plasma glucagon responses during hypoglycemia and either basal insulin secretion rates or B cell reserve. Thus, the findings of the present study argue that a simple paracrine islet A-B cell interaction is not the major determinant of the plasma glucagon response to hypoglycemia.

In the present studies, closed-loop infusion of insulin was used to maintain the diabetic subjects euglycemic overnight immediately before the induction of hypoglycemia; this resulted in modest peripheral hyperinsulinemia for $12-16 \mathrm{~h}$ in the diabetic subjects. Theoretically, this difference may have influenced the results of our experiments. However, for several reasons, this seems unlikely: first, the hyperinsulinemia was quite modest ( $11 \pm 2$ vs. $7 \pm 1 \mu \mathrm{U} / \mathrm{ml}$ in the nondiabetics), and similar fasting hyperinsulinemia is common in NIDDM patients $(42,43)$; second, basal rates of glucose production and utilization were normal in our diabetic subjects, indicating that the modest hyperinsulinemia was probably appropriate for the insulin resistance known to accompany $\operatorname{NIDDM}(42,43)$; third, subsequent plasma insulin concentrations after injection of insulin were not significantly different in the diabetics and nondiabetics; and finally, intensive insulin therapy in IDDM patients, which results in peripheral hyperinsulinemia (63), does not affect glucose counterregulation (64).

In summary, the present studies indicate that glucose counterregulatory mechanisms are defective in patients with NIDDM. Several abnormalities in the neuroendocrine response to hypoglycemia (decreased glucagon, growth hormone, cortisol, and perhaps epinephrine secretion) are associated with a lack of a compensatory increase in glucose production. A paradoxical and extended suppression of glucose utilization, which could be explained by an interaction between insulin resistance and actions of catecholamines in peripheral tissues, partially compensates for the defect in glucose production so that the net effect is only a modest prolongation of hypoglycemia. The negative correlation between plasma glucagon responses and suppression of insulin secretion observed in both nondiabetic and diabetic subjects provide evidence against the hypothesis that increases in plasma glucagon during hypoglycemia result primarily from deinhibition of the A cell via a paracrine islet A-B cell interaction.

\section{Acknowledgments}

The authors acknowledge the technical assistance of T. Lund, J. King, J. Kahl, V. Heiling, L. Hall, K. Kluge, S. Shah, the staff of the Mayo Clinical Study Unit, the secretarial assistance of P. Voelker, and the Clinical Department of Squibb-Novo, Inc. (Princeton, NJ) for their provision of C-peptide kits.

These studies were supported in part by U. S. Public Health Service grants AM20411, AM05827, RR00585, AM27085, AM20579, and RR00036. Dr. Bolli is the recipient of a grant from the Italian Diabetes Association.

\section{References}

1. Cryer, P. E., and J. E. Gerich. 1983. Relevance of glucose counterregulatory systems to patients with diabetes: critical roles of glucagon and epinephrine. Diabetes Care. 6:95-99.

2. Gerich, J., M. Langlois, C. Noacco, J. Karam, and P. Forsham. 1973. Lack of glucagon response to hypoglycemia in diabetes: evidence for an intrinsic pancreatic alpha-cell defect. Science (Wash. DC). 182:171173.

3. Campbell, L. V., E. W. Kraegen, H. Meler, and L. Lazards. 1979. Hormonal responses to insulin infusion in diabetes. Diabetologia. 16:359364.

4. Sacca, L., R. Sherwin, R. Hendler, and P. Felig. 1979. Influence of continuous physiologic hyperinsulinemia on glucose kinetics and counterregulatory hormones in normal and diabetic humans. J. Clin. Invest. 63:849-857.

5. Hilsted, J., S. Madsbad, T. Krarup, L. Sestoft, N. Christensen, B. Tronier, and H. Galbo. 1981. Hormonal, metabolic and cardiovascular responses to hypoglycemia in diabetic autonomic neuropathy. Diabetes. 30:626-633.

6. Popp, D., S. Shah, and P. Cryer. 1982. The role of epinephrinemediated beta adrenergic mechanisms in hypoglycemic glucose counterregulation and posthypoglycemic hyperglycemia in insulin-dependent diabetes mellitus. J. Clin. Invest. 69:315-326.

7. Bolli, G., P. De Feo, P. Compagnucci, M. Cartechini, G. Angelleti, F. Santeusanio, P. Brunetti, and J. Gerich. 1983. Abnormal glucose counterregulation in insulin dependent diabetes mellitus: interaction of anti-insulin antibodies and impaired glucagon and epinephrine secretion. Diabetes. 32:134-141.

8. Polonsky, K., R. Bergenstal, G. Pons, M. Schneider, J. Jaspan, and A. Rubenstein. 1982. Relation of counterregulatory responses to hypoglycemia in type I diabetics. N. Engl. J. Med. 307:1106-1112.

9. White, N. H., D. A. Skor, P. E. Cryer, L. A. Levandoski, D. M. Bier, and J. V. Santiago. 1983. Identification of type I diabetic patients at increased risk for hypoglycemia during intensive therapy. $N$. Engl. J. Med. 308:485-491.

10. Kleinbaum, J., and H. Shamoon. 1983. Impaired counterregulation of hypoglycemia in insulin-dependent diabetes mellitus. $\mathrm{Di}$ abetes. 32:493-498.

11. Boden, G., G. Reichard, R. Hoeldtke, I. Rezvani, and O. Owen. 1981. Severe insulin-induced hypoglycemia associated with deficiencies in the release of counterregulatory hormones. N. Engl. J. Med. 305:12001205.

12. Bolli, G., G. Dimitriadis, G. Pehling, B. Baker, M. Haymond, 
P. Cryer, and J. Gerich. 1983. Abnormal glucose counterregulation after subcutaneous insuln in insulin-dependent diabetes mellitus: exaggerated hypoglycemia and rebound hyperglycemia due to multiple counterregulatory hormone deficiencies and abnormal plasma insulin kinetics. Diabetes. 32(Suppl. 1):15A.

13. Reynolds, C., G. Molnar, D. Horwitz, A. Rubenstein, W. Taylor, and N. Jiang. 1977. Abnormalities of endogenous glucagon and insulin in unstable diabetes. Diabetes. 26:36-45.

14. Levitt, N., A. Vinik, A. Sive, P. Child, and W. Jackson. 1979. Studies on plasma glucagon concentration in maturity-onset diabetes without autonomic neuropathy. Diabetes. 28:1015-1021.

15. Boden, G., M. Soriano, R. Hoeldtke, and O. Owen. 1983. Counterregulatory hormone response and glucose recovery after hypoglycemia in non-insulin-dependent diabetic patients. Diabetes. 32:1055-1059.

16. Field, J., M. Ohta, C. Boyle, and A. Remer. 1967. Potentiation of acetohexamide hypoglycemia by phenylbutazone. N. Engl. J. Med. 277:899-894.

17. Frey, H., and B. Rosenlund. 1970. Studies in patients with chlorpropamide-induced hypoglycemia. Diabetes. 19:930-937.

18. Asplin, C., T. Paquette, and J. Palmer. 1981. In vivo inhibition of glucagon secretion by paracrine beta cell activity in man. J. Clin. Invest. 68:314-318.

19. Unger, R. 1983. Insulin-glucagon relationships in the defense against hypoglycemia. Diabetes. 32:575-583.

20. Gerich, J., M. Charles, and G. Grodsky. 1976. Regulation of pancreatic insulin and glucagon secretion. Annu. Rev. Physiol. 38:353388.

21. Perley, J., and D. Kipnis. 1967. Plasma insulin responses to oral and intravenous glucose studies in normal and diabetic subjects. J. Clin. Invest. 46:1954-1962.

22. Hilsted, J., and S. Jensen. 1979. A simple test for autonomic neuropathy in juvenile diabetics. Acta Med. Scand. 205:385-387.

23. Ewing, D., I. Campbell, A. Burt, and B. Clark. 1973. Vascular reflexes in diabetic autonomic neuropathy. Lancet II:1354-1356.

24. McGuire, E., J. Helderman, J. Tobin, R. Andres, and M. Berman. 1976. Effects of arterial versus venous sampling on analysis of glucose kinetics in man. J. Appl. Physiol. 41:565-573.

25. Dunn, A., J. Katz, S. Golden, and M. Chenoweth. 1976. Estimation of glucose turnover and recycling in rabbits using various $\left[{ }^{3} \mathrm{H},{ }^{14} \mathrm{C}\right]$ glucose labels. Am. J. Physiol. 230:1159-1162.

26. Nakagawa, S., H. Nakayama, T. Sasaki, K. Yoshino, Y. Yu, K. Shinozaki, S. Aoki, and K. Mashimo. 1973. A simple method for the determination of serum free insulin levels in insulin-treated patients. Diabetes. 22:590-600.

27. Faloona, G., and R. Unger. 1974. Glucagon. In Methods of Hormone Radioimmunoassay. B. Jaffe and H. Behrman, editors. Academic Press, Inc., New York. 317-330.

28. Faber, O., C. Binder, J. Markussen, L. Heding, V. Naithani, H. Kuzuya, P. Blix, D. Horwitz, and A. Rubenstin. 1978. Characterization of seven C-peptide antisera. Diabetes. 27(Suppl. 1):170-177.

29. Cryer, P., J. Santiago, and D. Shah. 1974. Measurement of norepinephrine and epinephrine in small volumes of human plasma by a single isotope derivative method: response to the upright posture. $J$. Clin. Endocrinol. Metab. 39:1025-1029.

30. Cortisol RAI Kit Protocol. Serono Labs, Inc. Randolph, MA.

31. Peake, G. 1974. Growth hormone. In Methods of Hormone Radioimmunoassay. B. Jaffe and H. Behrman, editors. Academic Press, Inc., New York. 103-121.

32. Miles, J., M. Haymond, and J. Gerich. 1982. Effects of free fatty acids, insulin, glucagon and adrenalin on ketone body production in humans. In Metabolic Acidosis. Ciba Foundation Symp. 87. Pitman Books, Ltd., London. 192-213.

33. Cahill, G. F., M. G. Herrera, A. P. Morgan, J. Soeldner, J. Steinke, P. L. Levy, G. A. Richards, and D. M. Kipnis. 1966. Hormone fuel interrelationship during fasting. J. Clin. Invest. 45:1751-1759.

34. DeBodo, R., R. Steele, N. Altszuler, A. Dunn, and J. Bishop. 1963. On the hormonal regulation of carbohydrate metabolism: studies with $C^{14}$-glucose. Recent Prog. Horm. Res. 19:445-488.

35. Miles, J., R. Glasscock, J. Aikens, J. Gerich, and M. Haymond. 1983. A microfluorimetric method for the determination of free fatty acids in plasma. J. Lipid Res. 24:96-99.

36. Eaton, R., R. Allen, D. Schade, K. Erickson, and J. Standefer. Prehepatic insulin production in man: kinetic analysis using peripheral connecting peptide behavior. J. Clin. Endocrinol. Metab. 51:520-528.

37. Faber, O., C. Hagen, C. Binder, J. Markunen, V. Naithani, P. Blix, H. Kuzuya, D. Horwitz, and A. Rubenstein. 1978. Kinetics of human connecting $\mathrm{C}$-peptide in normal and diabetic subjects. J. Clin. Invest. 62:197-203.

38. Goldman, J., D. Baldwin, W. Pugh, and A. Rubenstin. 1978. Equilibrium binding assay and kinetic characterization of insulin antibodies. Diabetes. 27:653-660.

39. Huisman, T., W. Schroeder, A. Brodie, S. Mayson, and J. Jakwy. 1975. Microchromatography of hemoglobin. III. A simplified procedure for the determination of hemoglobin $\mathrm{A}_{2}$. J. Lab. Clin. Med. 86:700702.

40. Snedecor, G., and W. Cochran. 1980. Statistical Methods. The Iowa State University Press, Ames, IA. Seventh edition.

41. Faber, O., and C. Binder. 1977. C-peptide response to glucagon: a test for the residual $\beta$-cell function in diabetes mellitus. Diabetes. 26:605-610.

42. Kolterman, O., R. Gray, J. Griffin, P. Burstein, J. Insel, J. Scarlett, and J. Olefsky. 1981. Receptor and postreceptor defects contribute to the insulin resistance in noninsulin-dependent diabetes mellitus. J. Clin. Invest. 68:957-969.

43. Mandarino, L., R. Rizza, and J. Gerich. 1984. Effects of prolonged sulfonylurea (Tolazamide) treatment on insulin secretion, insulin receptor binding, and postreceptor events in patients with noninsulin-dependent diabetes mellitus. Diabetes Care. In press.

44. Fradkin, J., H. Shamoon, P. Felig, and R. Sherwin. 1980. Evidence for an important role of changes in rather than absolute concentration of glucagon in the regulation of glucose production in humans. J. Clin. Endocrinol. Metab. 50:698-703.

45. Lines, P., A. Wajngot, U. Adamson, M. Vranic, and S. Effendic. Minimal increases in glucagon levels enhance glucose production in man with partial hypoinsulinemia. Diabetes. 32:633-636.

46. Rizza, R., P. Cryer, and J. Gerich. 1979. Role of glucagon, catecholamines, and growth hormone in human glucose counterregulation. Effects of somatostatin and combined $\alpha$-and $\beta$-adrenergic blockade on plasma glucose recovery and glucose flux rates after insulin-induced hypoglycemia. J. Clin. Invest. 64:62-71.

47. Rizza, R., L. Mandarino, and J. Gerich. 1982. Effects of growth hormone on insulin action in man: mechanisms of insulin resistance, impaired suppression of glucose production and impaired stimulation of glucose utilization. Diabetes. 31:663-669.

48. Rizza, R., L. Mandarino, and J. Gerich. 1982. Cortisol-induced insulin resistance in man: impaired suppression of glucose production and stimulation of glucose utilization due to a postreceptor defect of insulin action. J. Clin. Endocrinol. Metab. 54:131-138.

49. Bratusch-Marrain, P., D. Smith, and R. DeFronzo. 1982. Effect 
of growth hormone on glucose metabolism and insulin secretion in man. J. Clin. Endocrinol. Metab. 55:973-982.

50. Shamoon, H., R. Hendler, and R. Sherwin. 1981. Synergistic interactions among antiinsulin hormones in the pathogenesis of stress hyperglycemia in humans. J. Clin. Endocrinol. Metab. 52:1235-1241.

51. Gerich, J., R. Rizza, M. Haymond, and P. Cryer. 1980. Hormonal mechanisms in acute glucose counterregulation: the relative roles of glucagon, epinephrine, norepinephrine, growth hormone and cortisol. Metabolism. 29(Suppl. 1):1164-1175.

52. Garber, A., P. Cryer, J. Santiago, M. Haymond, A. Pagliara, and D. Kipnis. 1976. The role of adrenergic mechanisms in the substrate and hormonal response to insulin-induced hypoglycemia in man. $J$. Clin. Invest. 58:7-15.

53. Bolli, G., P. De Feo, P. Compagnucci, M. Cartechini, G. Angeletti, F. Santeusanio, and P. Brunetti. 1982. Important role of adrenergic mechanisms in acute glucose counterregulation following insulin-induced hypoglycemia in type I diabetes. Diabetes. 31:641-647.

54. Bergman, R., and R. Bucolo. 1974. Interaction of insulin and glucose in the control of hepatic glucose balance. Am. J. Physiol. 227:1314-1322.

55. Bolli, G., I. Gottesman, P. Cryer, and J. Gerich. 1984. Glucose counterregulation during prolonged hypoglycemia in normal man. Am. J. Physiol. 245 .

56. Silverberg, A., S. Shah, M. Haymond, and P. Cryer. 1978. Norepinephrine: hormone and neurotransmitter in man. Am. J. Physiol. 234:E252-E256.
57. Shamoon, H., and J. Kleinbaum. 1983. $\beta$-blockade delays glucose recovery from hypoglycemia by different mechanisms in normal and diabetic humans. Diabetes. 32(Suppl. 1):53A.

58. Rizza, R., P. Cryer, M. Haymond, and J. Gerich. 1980. Adrenergic mechanisms for the effects of epinephrine on glucose production and clearance in man. J. Clin. Invest. 65:682-689.

59. Shamoon, H., R. Hender, and R. Sherwin. 1980. Altered responsiveness to cortisol, epinephrine, and glucagon in insulin-infused juvenile-onset diabetes: a mechanism for diabetic instability. Diabetes. 29:284-291.

60. Campbell, L., E. Kraegen, and L. Lazarus. 1977. Defective blood glucose counterregulation in diabetes is a selective form of autonomic neuropathy. Br. Med. J. 2:1527-1529.

61. Day, J., and J. Anderson. 1973. Abnormalities of glucagon metabolism in diabetes mellitus. Clin. Endocrinol. 2:211-217.

62. Unger, R., P. Raskin, C. Srikant, and L. Orci. 1977. Glucagon and the A cells. Recent Prog. Horm. Res. 33:477-517.

63. Rizza, R., J. Gerich, M. Haymond, R. Westland, L. Hall, A. Clemens, and J. Service. 1980. Control of blood sugar in insulin-dependent diabetes: comparison of an artificial endocrine pancreas, continuous subcutaneous insulin infusion, and intensified conventional insulin therapy. N. Engl. J. Med. 303:1314-1318.

64. Bergenstal, R., K. Polonsky, G. Pons, J. Jaspan, and A. Rubenstein. 1983. Lack of glucagon response to hypoglycemia in type I diabetics after long-term optimal therapy with a continuous subcutaneous insulin infusion pump. Diabetes. 32:398-402. 